\title{
Cardiac resynchronization therapy; the importance of evaluating cardiac metabolism
}

\author{
E. E. van der Wall • M. J. Schalij • A. van der Laarse • \\ J. J. Bax
}

Received: 14 January 2010/ Accepted: 26 January 2010/Published online: 12 February 2010

(C) The Author(s) 2010. This article is published with open access at Springerlink.com

Cardiac resynchronization therapy (CRT) has shown to be an effective treatment for patients with advanced heart failure (HF) (NYHA Class III or IV), reduced left ventricular ejection fraction $(\mathrm{LVEF}<35 \%)$ and wide QRS complexes (>120 ms) [1,2]. The beneficial effects include improvement in heart failure symptoms, exercise capacity, and left ventricular function, as well as less heart failure hospitalizations and lower mortality rates. Despite these remarkable results, 30$40 \%$ of patients show no benefit after CRT, the so-called 'non-responders' [3-5]. It remains, however, difficult to distinguish responders from non-responders in the early period after CRT. The presence of LV dyssynchrony prior to implantation and its subsequent reduction after implantation are proposed as the key mechanisms for response to CRT [5, 6].

A variety of imaging modalities has already been applied to identify dyssynchrony and to evaluate the effects of CRT [7-10]. The use of echocardiography [11-17], magnetic resonance imaging (MRI) [18-29],

Editorial Comment to the article by Kitaizumi K, Yukiiri K, Masugata $\mathrm{H}$ et al. Acute Improvement of Cardiac Efficiency Measured by 11C-Acetate PET after Cardiac Resynchronization Therapy and Clinical Outcome (CAIM 1496)

E. E. van der Wall $(\bowtie) \cdot$ M. J. Schalij ·

A. van der Laarse $\cdot$ J. J. Bax

Department of Cardiology, Leiden University Medical Center, P.O. Box 9600, Leiden, The Netherlands

e-mail: e.e.van_der_wall@lumc.nl and multislice computed tomography (MSCT) [3043] has recently been proven for patients eligible for CRT. In addition, nuclear imaging techniques have become suited for the evaluation of LV dyssynchrony [44-51]. Until now, scintigraphic studies in CRT mainly concerned radionuclide angiography with phase image analysis [52-55]. In recent years positron emission tomography (PET) has emerged as a suitable modality to study the metabolic mechanisms of left ventricular dyssynchrony and the effects of CRT [56]. It has been reported that dyssynchrony influences regional myocardial workload, cardiac efficiency and oxygen metabolism as measured by carbon-11 (11C)-acetate PET. Several studies did already report that $11 \mathrm{C}$-acetate PET performed in the chronic phase after CRT showed improvement of oxygen metabolism and cardiac efficiency by CRT $[57,58]$. However, there are no data regarding the value of $11 \mathrm{C}$-acetate PET to predict responses to CRT in the acute phase after treatment.

In the current issue in the International Journal of Cardiovascular Imaging, Kitaizumi et al. [59] examined the usefulness of 11C-acetate PET for assessing the early efficacy of CRT in 20 patients with severe heart failure. All patients underwent 11C-acetate PET imaging within 1 week after CRT. Oxygen consumption was measured by the mono-exponential clearance rate of $11 \mathrm{C}$-acetate for both the patient's own beats (CRT off) and biventricular pacing (CRT-on). Plasma brain natriuretic peptide (BNP) levels were measured at 1, 3 and 12 months after installment of 
CRT. Oxygen consumption was measured by the mono-exponential clearance rate of $11 \mathrm{C}$-acetate (Kmono) for both CRT-off and CRT-on. Cardiac efficiency was determined using the work metabolic index (WMI), which was calculated as WMI = (stroke volume index $) \times($ systolic blood pressure $) \times$ (heart rate)/Kmono. Two groups of patients were discerned: 14 patients with improved cardiac efficiency and six patients with deteriorated cardiac efficiency by CRT-on. The mono-exponential clearance rate of $11 \mathrm{C}$-acetate decreased significantly by CRT-on in the improved cardiac efficiency group, but increased in the deteriorated- cardiac efficiency group. At 1-year follow-up, there were significantly higher rates of major cardiac adverse events in the deteriorated cardiac efficiency group than in the improved-cardiac efficiency group. Consequently, the decrease in oxygen consumption in the early period after CRT is a useful marker for predicting a good clinical outcome after CRT. The most impressive result of the study was that the patients with improved cardiac efficiency showed decreased oxygen consumption indicating improved oxidative metabolism with no changes in hemodynamic parameters in the early period after CRT. The authors concluded that improvement of cardiac efficiency, as assessed by $11 \mathrm{C}$-acetate PET in the early period after CRT, was produced by the decrease in oxygen consumption in patients showing good responses to CRT.

There are several caveats to the study, already recognized by the authors. Because of the relatively small population studied (20 patients), the authors were not able to address differences between non-ischemic (NICM) and ischemic (ICM) patients. These differences might be of importance, since Lindner et al. [60] showed that in patients with NICM CRT induces changes of myocardial oxygen consumption and myocardial blood flow on a regional level with a more uniform distribution between the myocardial walls and improved ventricular efficiency than in patients with ICM. Therefore, CRT might to be more effective in NICM than in ICM patients. Marsan et al. [61] questioned whether sequential biventricular pacing provides substantial benefits over conventional simultaneous stimulation, particularly regarding the differences between ICM and NICM patients. It was found that optimized sequential biventricular pacing further increased left ventricular systolic performance as compared to simultaneous stimulation; this finding held in particular for ICM patients where the presence of a large scar was correlated with a larger left ventricular pre-activation. So, ICIM and NICM patients should be separately considered in the evaluation of the effects of CRT therapy. Next, the PET studies were performed only once in the early period after CRT and not in the chronic phase. Comparison of PET data between acute and chronic phases may have more clearly shown the clinical use of PET to predict patient responses to CRT. However, the present results provide new information by showing that improved cardiac efficiency due to decreased oxygen metabolism may predict the improvement of cardiac function assessed by plasma BNP levels as well as predicting major adverse cardiac events after CRT.

To summarize, the study by Kitaizumi et al. [59] clearly shows that improvement of cardiac efficiency assessed by $11 \mathrm{C}$-acetate PET in the early period after CRT is caused by a decrease in oxygen consumption in patients who showed an adequate response to CRT. The decrease in oxygen consumption assessed by PET in the early period after CRT is therefore a potential marker to predict improvement of cardiac function and major cardiac events during the first year of follow-up. More metabolic cardiac studies are needed to unravel the basic mechanisms of left ventricular dyssynchrony in order to install the most appropriate therapy $[62,63]$.

Open Access This article is distributed under the terms of the Creative Commons Attribution Noncommercial License which permits any noncommercial use, distribution, and reproduction in any medium, provided the original author(s) and source are credited.

\section{References}

1. Bax JJ, Marwick TH, Molhoek SG et al (2003) Left ventricular dyssynchrony predicts benefit of cardiac resynchronization therapy in patients with end-stage heart failure before pacemaker implantation. Am J Cardiol 92:1238-1240

2. Bax JJ, Bleeker GB, Marwick TH et al (2004) Left ventricular dyssynchrony predicts response and prognosis after cardiac resynchronization therapy. J Am Coll Cardiol 44:1834-1840

3. Buck S, Maass AH, van Veldhuisen DJ, Van Gelder IC (2009) Cardiac resynchronisation therapy and the role of optimal device utilisation. Neth Heart J 17:354-357

4. van Hemel NM, Scheffer M (2009) Cardiac resynchronisation therapy in daily practice and loss of confidence in predictive techniques to response. Neth Heart J 17:4-5 
5. Bleeker GB, Holman ER, Steendijk P et al (2006) Cardiac resynchronization therapy in patients with a narrow $\mathrm{QRS}$ complex. J Am Coll Cardiol 48:2243-2250

6. Jansen AH, van Gelder BM (2008) Visual LV motion and invasive $\mathrm{LVdP} / \mathrm{dtmax}$ for selection and optimisation of cardiac resynchronisation therapy. Neth Heart J 16(Suppl 1):S32-S35

7. Sá MI, de Roos A, Westenberg JJ, Kroft LJ (2008) Imaging techniques in cardiac resynchronization therapy. Int $\mathbf{J}$ Cardiovasc Imaging 24:89-105

8. Ypenburg C, van der Wall EE, Schalij MJ, Bax JJ (2008) Imaging in cardiac resynchronisation therapy. Neth Heart $\mathrm{J}$ 16:S36-S40

9. Ypenburg C, Westenberg JJ, Bleeker GB et al (2008) Noninvasive imaging in cardiac resynchronization therapy-part 1: selection of patients. Pacing Clin Electrophysiol 31:1475-1499

10. Van de Veire NR, Delgado V, Schuijf JD, van der Wall EE, Schalij MJ, Bax JJ (2009) The role of non-invasive imaging in patient selection. Europace 11(Suppl 5):v32-v39

11. Bleeker GB, Bax JJ, Fung JW et al (2006) Clinical versus echocardiographic parameters to assess response to cardiac resynchronization therapy. Am J Cardiol 97:260-263

12. Bleeker GB, Yu CM, Nihoyannopoulos P et al (2007) Optimal use of echocardiography in cardiac resynchronisation therapy. Heart 93:1339-1350

13. Bleeker GB, Schalij MJ, Boersma E et al (2007) Relative merits of M-mode echocardiography and tissue Doppler imaging for prediction of response to cardiac resynchronization therapy in patients with heart failure secondary to ischemic or idiopathic dilated cardiomyopathy. Am J Cardiol 99:68-74

14. Bertini M, Marsan NA, Delgado V et al (2009) Effects of cardiac resynchronization therapy on left ventricular twist. J Am Coll Cardiol 54:1317-1325

15. Tops LF, Suffoletto MS, Bleeker GB et al (2007) Speckletracking radial strain reveals left ventricular dyssynchrony in patients with permanent right ventricular pacing. J Am Coll Cardiol 50:1180-1188

16. Shi H, Shu X, Wang F et al (2009) Longitudinal twodimensional strain rate imaging: a potential approach to predict the response to cardiac resynchronization therapy. Int J Cardiovasc Imaging 25:677-687

17. Pavlopoulos H, Nihoyannopoulos P (2010) Recent advances in cardiac resynchronization therapy: echocardiographic modalities, patient selection, optimization, non-respondersall you need to know for more efficient CRT. Int J Cardiovasc Imaging (Epub ahead of publication)

18. van der Wall EE, van Dijkman PR, de Roos A et al (1990) Diagnostic significance of gadolinium-DTPA (diethylenetriamine penta-acetic acid) enhanced magnetic resonance imaging in thrombolytic treatment for acute myocardial infarction: its potential in assessing reperfusion. Br Heart $\mathbf{J}$ 63:12-17

19. van Dijkman PR, van der Wall EE, de Roos A et al (1991) Acute, subacute, and chronic myocardial infarction: quantitative analysis of gadolinium-enhanced MR images. Radiology 180:147-151

20. de Roos A, Matheijssen NA, Doornbos J, van Dijkman PR, van Voorthuisen AE, van der Wall EE (1990) Myocardial infarct size after reperfusion therapy: assessment with GdDTPA-enhanced MR imaging. Radiology 176:517-521

21. Pluim BM, Lamb HJ, Kayser HW et al (1998) Functional and metabolic evaluation of the athlete's heart by magnetic resonance imaging and dobutamine stress magnetic resonance spectroscopy. Circulation 97:666-672

22. Vliegen HW, Doornbos J, de Roos A, Jukema JW, Bekedam MA, van der Wall EE (1997) Value of fast gradient echo magnetic resonance angiography as an adjunct to coronary arteriography in detecting and confirming the course of clinically significant coronary artery anomalies. Am J Cardiol 79:773-776

23. Hoogendoorn LI, Pattynama PM, Buis B, van der Geest RJ, van der Wall EE, de Roos A (1995) Noninvasive evaluation of aortocoronary bypass grafts with magnetic resonance flow mapping. Am J Cardiol 75:845-848

24. Holman ER, Buller VG, de Roos A et al (1997) Detection and quantification of dysfunctional myocardium by magnetic resonance imaging. A new three-dimensional method for quantitative wall-thickening analysis. Circulation 95:924-931

25. Schuijf JD, Bax JJ, van der Wall EE (2007) Anatomical and functional imaging techniques: basically similar or fundamentally different? Neth Heart J 15:43-44

26. Ypenburg C, Roes SD, Bleeker GB et al (2007) Effect of total scar burden on contrast-enhanced magnetic resonance imaging on response to cardiac resynchronization therapy. Am J Cardiol 99:657-660

27. Rüssel IK, van Dijk J, Kleijn SA et al (2009) Relation between three-dimensional echocardiography derived left ventricular volume and MRI derived circumferential strain in patients eligible for cardiac resynchronization therapy. Int J Cardiovasc Imaging 25:1-11

28. Westenberg JJ, Lamb HJ, van der Geest RJ et al (2006) Assessment of left ventricular dyssynchrony in patients with conduction delay and idiopathic dilated cardiomyopathy: head-to-head comparison between tissue doppler imaging and velocity-encoded magnetic resonance imaging. J Am Coll Cardiol 47:2042-2048

29. Bleeker GB, Kaandorp TA, Lamb HJ et al (2006) Effect of posterolateral scar tissue on clinical and echocardiographic improvement after cardiac resynchronization therapy. Circulation 113:969-976

30. Schuijf JD, Pundziute G, Jukema JW et al (2006) Diagnostic accuracy of 64-slice multislice computed tomography in the noninvasive evaluation of significant coronary artery disease. Am J Cardiol 98:145-148

31. Groen JM, Greuter MJ, Vliegenthart R et al (2008) Calcium scoring using 64-slice MDCT, dual source CT and EBT: a comparative phantom study. Int $\mathrm{J}$ Cardiovasc Imaging 24:547-556

32. de Leeuw JG, Wardeh A, Sramek A, van der Wall EE (2007) Pseudo-aortic dissection after primary PCI. Neth Heart J 15:265-266

33. Braun S, van der Wall EE, Emanuelsson S, Kobrin I (1996) Effects of a new calcium antagonist, mibefradil (Ro 405967), on silent ischemia in patients with stable chronic angina pectoris: a multicenter placebo-controlled study. The mibefradil international study group. J Am Coll Cardiol 27:317-322 
34. Portegies MC, Schmitt R, Kraaij CJ et al (1991) Lack of negative inotropic effects of the new calcium antagonist Ro 40-5967 in patients with stable angina pectoris. J Cardiovasc Pharmacol 18:746-751

35. ten Kate GJ, Wuestink AC, de Feyter PJ (2008) Coronary artery anomalies detected by MSCT-angiography in the adult. Neth Heart J 16:369-375

36. Bakx AL, van der Wall EE, Braun S, Emanuelsson H, Bruschke AV, Kobrin I (1995) Effects of the new calcium antagonist mibefradil (Ro 40-5967) on exercise duration in patients with chronic stable angina pectoris: a multicenter, placebo-controlled study. Ro 40-5967 International Study Group. Am Heart J 130:748-757

37. Schuijf JD, Jukema JW, van der Wall EE, Bax JJ (2007) Multi-slice computed tomography in the evaluation of patients with acute chest pain. Acute Card Care 9:214221

38. Henneman MM, Schuijf JD, Pundziute G et al (2008) Noninvasive evaluation with multislice computed tomography in suspected acute coronary syndrome: plaque morphology on multislice computed tomography versus coronary calcium score. J Am Coll Cardiol 52:216-222

39. de Nooijer R, Verkleij CJ, von der Thüsen JH et al (2006) Lesional overexpression of matrix metalloproteinase-9 promotes intraplaque hemorrhage in advanced lesions but not at earlier stages of atherogenesis. Arterioscler Thromb Vasc Biol 26:340-346

40. van der Laarse A, Kerkhof PL, Vermeer F et al (1988) Relation between infarct size and left ventricular performance assessed in patients with first acute myocardial infarction randomized to intracoronary thrombolytic therapy or to conventional treatment. Am J Cardiol 61:1-7

41. van der Hoeven BL, Pires NM, Warda HM et al (2005) Drug-eluting stents: results, promises and problems. Int $\mathbf{J}$ Cardiol 99:9-17

42. Jongbloed MR, Lamb HJ, Bax JJ et al (2005) Noninvasive visualization of the cardiac venous system using multislice computed tomography. J Am Coll Cardiol 45:749-753

43. Van de Veire NR, Schuijf JD et al (2006) Non-invasive visualization of the cardiac venous system in coronary artery disease patients using 64-slice computed tomography. J Am Coll Cardiol 48:1832-1838

44. van der Wall EE, Heidendal GA, den Hollander W, Westera G, Roos JP (1980) I-123 labeled hexadecenoic acid in comparison with thallium-201 for myocardial imaging in coronary heart disease. A preliminary study. Eur J Nucl Med 5:401-405

45. Bax JJ, Lamb H, Dibbets P et al (2000) Comparison of gated single-photon emission computed tomography with magnetic resonance imaging for evaluation of left ventricular function in ischemic cardiomyopathy. Am J Cardiol 86:1299-1305

46. Bavelaar-Croon CD, Pauwels EK, van der Wall EE (2001) Gated single-photon emission computed tomographic myocardial imaging: a new tool in clinical cardiology. Am Heart J 141:383-390

47. Chamuleau SA, van Eck-Smit BL, Meuwissen $M$ et al (2007) Long-term prognostic value of CFVR and FFR versus perfusion scintigraphy in patients with multivessel disease. Neth Heart J 15:369-374
48. Bavelaar-Croon CD, Kayser HW, van der Wall EE et al (2000) Left ventricular function: correlation of quantitative gated SPECT and MR imaging over a wide range of values. Radiology 217:572-575

49. van Rugge FP, Boreel JJ, van der Wall EE et al (1991) Cardiac first-pass and myocardial perfusion in normal subjects assessed by sub-second Gd-DTPA enhanced MR imaging. J Comput Assist Tomogr 15:959-965

50. van der Wall EE, den Hollander W, Heidendal GA, Westera G, Majid PA, Roos JP (1981) Dynamic myocardial scintigraphy with 123I-labeled free fatty acids in patients with myocardial infarction. Eur $\mathrm{J}$ Nucl Med 6:383-389

51. Ypenburg C, Schalij MJ, Bleeker GB et al (2006) Extent of viability to predict response to cardiac resynchronization therapy in ischemic heart failure patients. J Nucl Med 47:1565-1570

52. Henneman MM, van der Wall EE, Ypenburg C et al (2007) Nuclear imaging in cardiac resynchronization therapy. J Nucl Med 48:2001-2010

53. Boogers MM, Chen J, Bax JJ (2008) Myocardial perfusion single photon emission computed tomography for the assessment of mechanical dyssynchrony. Curr Opin Cardiol 23:431-439

54. Wassenaar R, O'Connor D, Dej B, Ruddy TD, Birnie D (2009) Optimization and validation of radionuclide angiography phase analysis parameters for quantification of mechanical dyssynchrony. J Nucl Cardiol 16: 895-903

55. Henneman MM, Chen J, Dibbets-Schneider P et al (2007) Dyssynchrony as assessed with phase analysis on gated myocardial perfusion SPECT predict response to CRT? J Nucl Med 48:1104-1111

56. Ukkonen H, Beanlands RS, Burwash IG et al (2003) Effect of cardiac resynchronization on myocardial efficiency and regional oxidative metabolism. Circulation 107:28-31

57. Knuuti J, Sundell J, Naum A et al (2004) Assessment of right ventricular oxidative metabolism by PET in patients with idiopathic dilated cardiomyopathy undergoing cardiac resynchronization therapy. Eur J Nucl Med Mol Imaging 31:1592-1598

58. Lindner O, Sörensen J, Vogt J et al (2006) Cardiac efficiency and oxygen consumption measured with 11C-acetate PET after long-term cardiac resynchronization therapy. J Nucl Med 47:378-383

59. Kitaizumi K, Yukiiri K, Masugata H et al. (2010) Acute Improvement of Cardiac Efficiency Measured by 11CAcetate PET after Cardiac Resynchronization Therapy and Clinical Outcome. Int J Cardiovasc Imaging (Epub ahead of publication)

60. Lindner O, Vogt J, Kammeier A et al (2005) Effect of cardiac resynchronization therapy on global and regional oxygen consumption and myocardial blood flow in patients with non-ischaemic and ischaemic cardiomyopathy. Eur Heart J 26:70-76

61. Marsan NA, Bleeker GB, Van Bommel RJ et al (2009) Cardiac resynchronization therapy in patients with ischemic versus non-ischemic heart failure: differential effect of optimizing interventricular pacing interval. Am Heart $\mathbf{J}$ 158:769-776 
62. Umar S, Bax JJ, Klok M et al (2008) Myocardial collagen metabolism in failing hearts before and during cardiac resynchronization therapy. Eur J Heart Fail 10:878-883

63. Tops LF, Bax JJ, Zeppenfeld K et al (2005) Fusion of multislice computed tomography imaging with three- dimensional electroanatomic mapping to guide radiofrequency catheter ablation procedures. Heart Rhythm 2:1076-1081 